\title{
Numbers, Densities, and Colocalization of AMPA- and NMDA-Type Glutamate Receptors at Individual Synapses in the Superficial Spinal Dorsal Horn of Rats
}

\author{
Miklós Antal, ${ }^{1 \star}$ Yugo Fukazawa, ${ }^{4 \star}$ Mária Eördögh, ${ }^{1}$ Dóra Muszil, ${ }^{1}$ Elek Molnár, ${ }^{2}$ Makoto Itakura, ${ }^{3}$ Masami Takahashi, ${ }^{3}$ \\ and Ryuichi Shigemoto ${ }^{4}$ \\ ${ }^{1}$ Department of Anatomy, Histology, and Embryology, Faculty of Medicine, Medical and Health Science Center, University of Debrecen, H-4012 Debrecen, \\ Hungary, ${ }^{2}$ Medical Research Council, Centre for Synaptic Plasticity, Department of Anatomy, School of Medical Sciences, University of Bristol, Bristol BS8 \\ 1TD, United Kingdom, ${ }^{3}$ Department of Biochemistry, Kitasato University School of Medicine, Sagamihara, Kanagawa 228-8555, Japan, and ${ }^{4}$ Division of \\ Cerebral Structures, National Institutes for Physiological Sciences, Myodaiji, Okazaki 444-8787, Japan
}

Ionotropic glutamate receptors play important roles in spinal processing of nociceptive sensory signals and induction of central sensitization in chronic pain. Here we applied highly sensitive freeze-fracture replica labeling to laminae I-II of the spinal dorsal horn of rats and investigated the numbers, densities, and colocalization of AMPA- and NMDA-type glutamate receptors at individual postsynaptic membrane specializations with a high resolution. All glutamatergic postsynaptic membranes in laminae I-II expressed AMPA receptors, and most of them (96\%) were also immunoreactive for the NR1 subunit of NMDA receptors. The numbers of gold particles for AMPA and NMDA receptors at individual postsynaptic membranes showed a linear correlation with the size of postsynaptic membrane specializations and varied in the range of 8-214 and 5-232 with median values of 37 and 28, whereas their densities varied in the range of $325-3365 / \mu \mathrm{m}^{2}$ and $102-2263 / \mu \mathrm{m}^{2}$ with median values of $1115 / \mu \mathrm{m}^{2}$ and $777 / \mu \mathrm{m}^{2}$, respectively. Virtually all (99\%) glutamatergic postsynaptic membranes expressed GluR2, and most of them (87\%) were also immunoreactive for GluR1. The numbers of gold particles for pan-AMPA, NR1, and GluR2 subunits showed a linear correlation with the size of postsynaptic surface areas. Concerning GluR1, there may be two populations of synapses with high and low GluR1 densities. In synapses larger than $0.1 \mu \mathrm{m}^{2}$, GluR1 subunits were recovered in very low numbers. Differential expression of GluR1 and GluR2 subunits suggests regulation of AMPA receptor subunit composition by presynaptic mechanism.

Key words: ionotropic glutamate receptors; NR1; GluR1; GluR2; molecular anatomy; postsynaptic active zones; SDS-FRL

\section{Introduction}

Fast excitatory neurotransmission in the CNS is mainly mediated by glutamate. In the superficial spinal dorsal horn, glutamate is released by nociceptive primary afferents and local axon terminals of spinal excitatory neurons and, by activating ionotropic and metabotropic glutamate receptors, plays major roles in nociceptive information processing. In case of their repetitive stimulation, central terminals of nociceptive primary afferents discharge glutamate together with neuropeptides and neurotrophins. The interplay of glutamate, neuropeptide, and neurotrophin receptor mechanisms then results in increased

Received Dec. 19, 2007; revised Aug. 15, 2008; accepted Aug. 19, 2008.

This work was supported by the Hungarian National Research Fund (OTKA 46121; M.A.), Hungarian Scientific Council of Health (ETT 079/2006; M.A.), Hungarian Academy of Sciences (MTA-TKI 242; M.A.), Solution Oriented Research for Science and Technology from the Japan Science and Technology Agency (R.S.), Ministry of Education, Culture, Sports, Science, and Technology (Y.F., R.S.), and the United Kingdom Medical Research Council (E.M.).

*M.A. and Y.F. contributed equally to this work.

Correspondence should be addressed to Miklós Antal, Department of Anatomy, Histology, and Embryology, Faculty of Medicine, Medical and Health Science Center, University of Debrecen, Nagyerdei krt 98, H-4012 Debrecen, Hungary. E-mail:anta@@chondron.anat.dote.hu.

DOI:10.1523/JNEUROSCI.1551-08.2008

Copyright $\odot 2008$ Society for Neuroscience $\quad$ 0270-6474/08/289692-10\$15.00/0
$\mathrm{Ca}^{2+}$ influx into the postsynaptic spinal neurons and the consequent development of central sensitization, which presents common features with the early phase of long-term potentiation (LTP). The propagation of enhanced activities of spinal nociceptive circuits to higher brain centers then leads to hyperalgesia and various pain syndromes (Woolf and Salter, 2000). A long line of evidence indicates that AMPA and NMDA receptors are involved in the induction of spinal LTP and consequent pain (for review, see Ji et al., 2003).

It has been demonstrated extensively that AMPA and NMDA receptors are expressed in high densities in the superficial spinal dorsal horn (Furuyama et al., 1993; Pellegrini-Giampietro et al., 1994; Tachibana et al., 1994; Jakowec et al., 1995a,b; Harris et al., 1996; A. Popratiloff et al., 1996, 1998; S. A. Popratiloff et al., 1998; Kerr et al., 1998). The majority of AMPA receptors in the dorsal horn consist of GluR2 and GluR1 subunits that may form functional AMPA receptor ion channels in both homomeric and heteromeric arrangements. In contrast, the expression of GluR3 and GluR4 subunits and their mRNAs was found to be weak (Sato et al., 1993; Tölle et al., 1993, 1995).

Although a long line of experiments have been performed to detect AMPA and NMDA receptors in the spinal dorsal horn, 
these studies could reveal the receptors mostly, if not exclusively, in the cytoplasm and not at synaptic appositions. Postsynaptic membranes are poorly accessible for antibodies in preembedding immunostaining protocols because of the presence of extensive protein meshwork in the synaptic cleft and postsynaptic density (Baude et al., 1995; Ottersen and Landsend, 1997; Fritschy et al., 1998; Watanabe et al., 1998). Although postembedding immunogold labeling has also been used to investigate synaptic AMPA and NMDA receptors in the spinal cord (A. Popratiloff et al., 1996, 1998; S. A. Popratiloff et al., 1998; Ragnarson et al., 2003), the pattern of AMPA and NMDA receptor expression at individual synapses remains largely elusive.

Recently an SDS-digested freeze-fracture replica labeling (SDS-FRL) method was developed to investigate AMPA receptors at individual synapses (Tanaka et al., 2005; Masugi-Tokita et al., 2007). By removing attached molecules from the fractured plasma membranes, thus making intramembrane proteins directly accessible for antibodies, the SDS-FRL method seems to be ideal for immunocytochemical investigation of membranebound molecules, including neurotransmitter receptors (Masugi-Tokita and Shigemoto, 2007). In the present study, we applied the SDS-FRL method for AMPA and NMDA receptors in the superficial spinal dorsal horn of rats, which allowed us to examine the numbers, densities, and colocalization of these receptors at individual postsynaptic membranes with a high resolution.

\section{Materials and Methods}

Animals and preparation of tissue sections. Experiments were performed on three adult male Wistar rats, two GluR2 knock-out (Hartmann et al., 2004), one GluR1 knock-out (Hartmann et al., 2004), and two wild-type mice. Care and handling of the animals before and during the experiments followed European Union and Japanese regulations and was approved by the animal care and use committees of the authors' institutions. The animals were deeply anesthetized by sodium pentobarbital (3.5 mg/100 g of body weight, i.p.), and transcardially perfused with isotonic saline solution for $10-15 \mathrm{~min}$ followed by a fixative containing $2 \%$ paraformaldehyde and $15 \%$ saturated picric acid dissolved in $0.1 \mathrm{M}$ phosphate buffer (PB; pH 7.4). The perfusion with the fixative lasted for $30-40 \mathrm{~min}$, and then the lumbar segments (L2-L5) of the spinal cord were immediately excised and hemisected along the midline. The hemisected cords were transferred into $0.1 \mathrm{M} \mathrm{PB}, \mathrm{pH} 7.4$, for $1-2 \mathrm{~h}$. Then $150-\mu \mathrm{m}$-thick parasagittal sections were cut from the hemisected cords with a vibratome. After extensive washes in $0.1 \mathrm{M} \mathrm{PB}$, the sections were cryoprotected in $30 \%$ glycerol dissolved in $0.1 \mathrm{M}$ PB overnight. The fixed tissues were kept at $4^{\circ} \mathrm{C}$ until they were cryopreserved by freezing.

SDS-digested freeze-fracture replica labeling. The sections were frozen quickly by a high-pressure freezing machine (HPM 010; Bal-Tec). The frozen slices were then freeze fractured and coated with carbon $(5 \mathrm{~nm})$, shadowed by platinum $(2 \mathrm{~nm})$, and then coated with carbon $(15 \mathrm{~nm})$ again in BAF 060 (Bal-Tec). After thawing, tissue debris attached to the replicas was digested with gentle stirring at $80^{\circ} \mathrm{C}$ overnight in a solution containing $2.5 \%$ SDS and 20\% sucrose dissolved in $15 \mathrm{~mm}$ Tris buffer, $\mathrm{pH}$ 8.3. The replicas were washed in $25 \mathrm{~mm}$ Tris-buffered isotonic saline (TBS; pH 7.4) washing buffer containing $0.05 \%$ bovine serum albumin (BSA) and incubated in a blocking solution containing 5\% BSA in $25 \mathrm{~mm}$ TBS for $1 \mathrm{~h}$. Subsequently, the replicas were reacted with the following primary antibodies: (1) pan-AMPA receptor (GluR1-4) antibody raised in rabbit ( $1 \mu \mathrm{g} / \mathrm{ml}$ ) (Nusser et al., 1998), (2) mouse monoclonal antibody against the NR1 subunit of NMDA receptor $(1 \mu \mathrm{g} / \mathrm{ml}$; Millipore Bioscience Research Reagents), (3) mixture of the pan-AMPA and NR1 antibodies, (4) antibody against the GluR1 subunit of AMPA receptor raised in rabbit ( $8 \mu \mathrm{g} / \mathrm{ml})$, or (5) mouse monoclonal antibody against the GluR2 subunit of AMPA receptors ( $15 \mu \mathrm{g} / \mathrm{ml}$; Millipore Bioscience Research Reagents), diluted in $25 \mathrm{~mm}$ TBS containing $1 \% \mathrm{BSA}$ at $+15^{\circ} \mathrm{C}$ (in case of 1-3) or at room temperature (in case of 4-5) for $2 \mathrm{~d}$. The rabbit

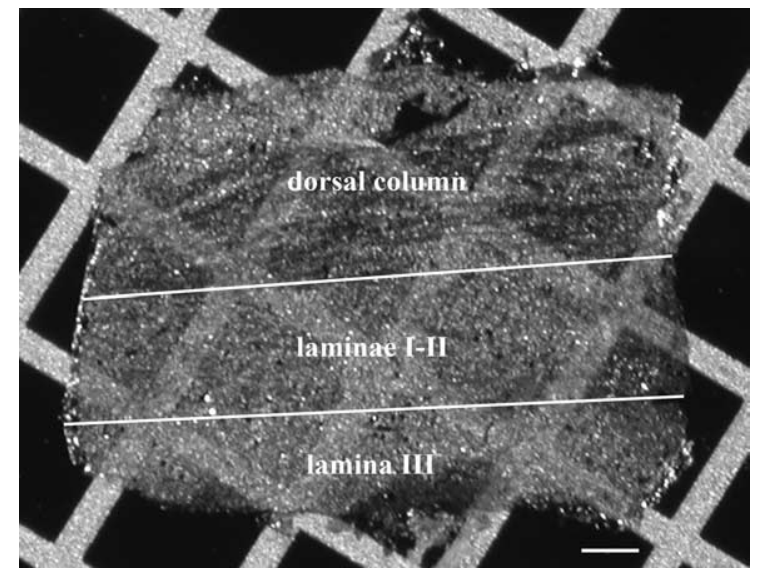

Figure 1. Photomicrograph of an SDS-FRL replica on a 100-mesh copper grid. The replica was prepared from a paramedian-sagittal section of the dorsal aspect of the rat lumbar spinal cord. White lines indicate the presumed outer and inner borders of laminae I-II. Scale bar, 100 $\mu \mathrm{m}$.

antibody against GluR1 was raised against an extracellular epitope (amino acid residues 345-362) of the rat GluR1 (CRFEGLTGNVQFNEKGRRT), followed by affinity purification with the same peptide. Subsequently, the antibody was absorbed twice by GluR2specific peptide (C-QVEGLSGNIKFDQNGKRI) to avoid undesired contamination of GluR2-reacting antibodies. After several washes, the replicas were reacted with goat anti-rabbit (for pan-AMPA and GluR1) and goat anti-mouse (for NR1 and GluR2) IgGs coupled to $5 \mathrm{~nm}$ gold particles (1:30; BioCell Research Laboratories) diluted in $25 \mathrm{~mm}$ TBS containing $5 \%$ BSA overnight at room temperature. In the doublelabeling protocols, one of the secondary antibodies was conjugated to 5 $\mathrm{nm}$ gold particle, whereas the other was coupled to $10 \mathrm{~nm}$ gold particle. The replicas were then washed, picked up on 100-mesh grids (Fig. 1), examined with an electron microscope (JEOL1010), and photographed at a magnification of $40,000 \times$.

Controls. To test the specificity of antibodies raised against GluR1 and GluR2 subunits of AMPA receptors, replicas of spinal cord sections obtained from GluR1 and GluR2 knock-out and wild-type mice were immunolabeled according to the procedure described above. Replicas of GluR2 knock-out mice were almost negative for GluR2 in the postsynaptic membrane specialization. On the average, the density value for GluR2 in the knock-out mice was 3.3 particles $/ \mu \mathrm{m}^{2}$, whereas that in the wild-type animals was 219 particles $/ \mu \mathrm{m}^{2}$. On the other hand, the antibody raised against GluR1 appeared to be highly specific and reacted selectively with GluR1 subunits in Western blot analysis (supplemental Fig. 1, available at www.jneurosci.org as supplemental material) However, labeling density for GluR1 at individual postsynaptic membrane specializations in wild type $(144 \pm 13.9 ; n=58)$ was only three times higher than that in knock-out mice ( $54 \pm 7.1 ; n=50$ ), although the difference was statistically significant $(p<0.001$, Mann-Whitney $U$ test) (supplemental Fig. 2, available at www.jneurosci.org as supplemental material). Therefore, we subtracted the density of non-GluR1 labeling from the labeling in wild type, thus making the density $63 \%$ of the original value.

Specificity of primary antibodies against NR1 and pan-AMPA was extensively characterized previously (Siegel et al., 1994; Nusser et al., 1998; Masugi-Tokita et al., 2007).

To test the specificity of the immunolabeling procedure, replicas were incubated according to the protocol described above with primary antibodies omitted or replaced with $1 \%$ normal goat serum. Labeling densities on clusters of intramembrane particles were $<2.8$ particles $/ \mu \mathrm{m}^{2}$ in these cases.

Quantitative evaluation of the immunolabeling. Immunogold particles were counted in excitatory postsynaptic areas indicated by clusters of intramembrane particles (IMP clusters) (Harris and Landis, 1986) on the exoplasmic fracture face (E-face) of plasma membranes. Aggregations of 
intramembrane particles were regarded as IMP clusters if the particles showed a compact arrangement in which the distances among adjacent particles were not larger than $15 \mathrm{~nm}$. We considered an IMP cluster as postsynaptic membrane specialization if the cluster contained at least 30 particles. Confirming the findings of Masugi-Tokita et al. (2007), all of the postsynaptic areas on E-face were labeled with the antibody raised against pan-AMPA. Immunogold particles were regarded as associated with the postsynaptic membrane specialization if they were above or in the immediate vicinity (not further than $20 \mathrm{~nm}$ from the edge) of the IMP cluster (Matsubara et al., 1996).

Measurements were performed in three animals, and results were pooled because the density for immunogold particles on IMP clusters was not significantly different in the different animals. Immunogold particles on the protoplasmic fracture face (P-face) of plasma membranes should not be labeled with antibodies directed against extracellular epitopes, and thus were defined as background labeling, which turned out to be 3.2 particles $/ \mu \mathrm{m}^{2}$ on the average. The extent of IMP clusters on electron micrographs was calibrated by using a calibration grid (Ted Pella). The outline of postsynaptic active zones (IMP clusters) was demarcated freehand, and the area of synaptic sites was measured by Scion Image. The numbers of gold particles marking receptor molecules at synaptic sites were counted manually.

Statistical analysis of distribution pattern of immunogold particles. To evaluate the distribution pattern of gold particles labeling receptors within a synapse, we used point pattern analysis using Ripley's K-function (Ripley, 1977, 1979; Prior et al., 2003). Electron micrographs of six randomly selected IMP clusters labeled for NR1, pan-AMPAR, GluR1, and GluR2 were digitized with an image scanner. A rectangular area that covered at least $50 \%$ of particles at individual IMP clusters was selected, and the $x-y$ coordinates of individual particles in the area were obtained by iTEM image analysis software (Soft Imaging System). Distribution patterns of immunogold particles were analyzed with the $L(r)-r$ values, which express the second-order spatial pattern of particle distribution based on the interparticle distances within the studied area, by using a program kindly provided by John Hancock, University of Queensland, Brisbane, Australia (Prior et al., 2003). To define whether the distribution patterns of immunogold particles were homogeneous or clustered, $99 \%$ confidence envelopes for complete spatial randomness (CSR) were generated from 100 Monte Carlo simulations and plotted with the $L(r)-r$ curve (see supplemental Fig. 3, available at www.jneurosci.org as supplemental material). When the $L(r)-r$ curve was above the envelope at more than one point, distribution was classified as clustered. When all points of the $L(r)-r$ curve were below the envelope, its distribution was classified as CSR and as homogeneous. For more detailed information about the application of this statistical approach to immunoparticle-labeled replicas, please see Fujita et al. (2007).

\section{Results}

Numbers and densities of AMPA receptors at individual synaptic contact areas

Using the SDS-FRL method, we analyzed the numbers, distribution, and densities of AMPA receptors at individual synaptic contact areas in the superficial spinal dorsal horn of rats with an antibody against highly conserved extracellular amino acid residues of GluR1-4 (pan-AMPA). The pan-AMPA antibody has been shown to react selectively with all AMPA receptor subunits
GluR1-4, but not with kainate receptor subunits (Nusser et al., 1998).

The border between the dorsal column and the dorsal horn was easily identified on the replicas with both light and electron microscopy (Fig. 1). The border between laminae II and III was also clear because almost no myelinated axons were found in lamina II, but many were in lamina III. Immunoreactivity of IMP clusters on E-face profiles of the replicas was investigated in a band between these two boundaries (Fig. 1), in a zone that had earlier been identified as a layer of the gray matter corresponding to laminae I and II of the spinal dorsal horn (McClung and Castro, 1978; Molander et al., 1984; McNeill et al., 1988).

Postsynaptic membrane specializations were clearly indicated by aggregations of IMPs on E-faces (see Figs. 2, 5, 6), as described previously (Landis and Reese, 1974; Harris and Landis, 1986). We defined IMP clusters as those containing at least 30 intramembrane particles. Immunogold particles for AMPA receptors were found almost exclusively on IMP clusters, and all IMP clusters on E-face profiles were immunoreactive for the pan-AMPA antibody (Fig. $2 a, c)$. In the majority of postsynaptic membrane specializations, immunogold particles were distributed over the entire field of individual IMP clusters with no apparent clustering (Fig. 2a; supplemental Fig. 2, available at www.jneurosci.org as supplemental material), although the density of labeling varied considerably from cluster to cluster (Fig. $3 a$ ). The number of immunogold particles was counted in both complete $(n=97)$ and incomplete (partially fractured; $n=65$ ) postsynaptic membrane specializations. In complete postsynaptic membrane specializations, the number of gold particles varied in the range of $8-214$ with a median value of 37 . The number of gold particles labeling AMPA receptor showed a linear correlation $(r=0.86)$ with the size of the postsynaptic surface areas (Fig. $4 a$ ). Because 

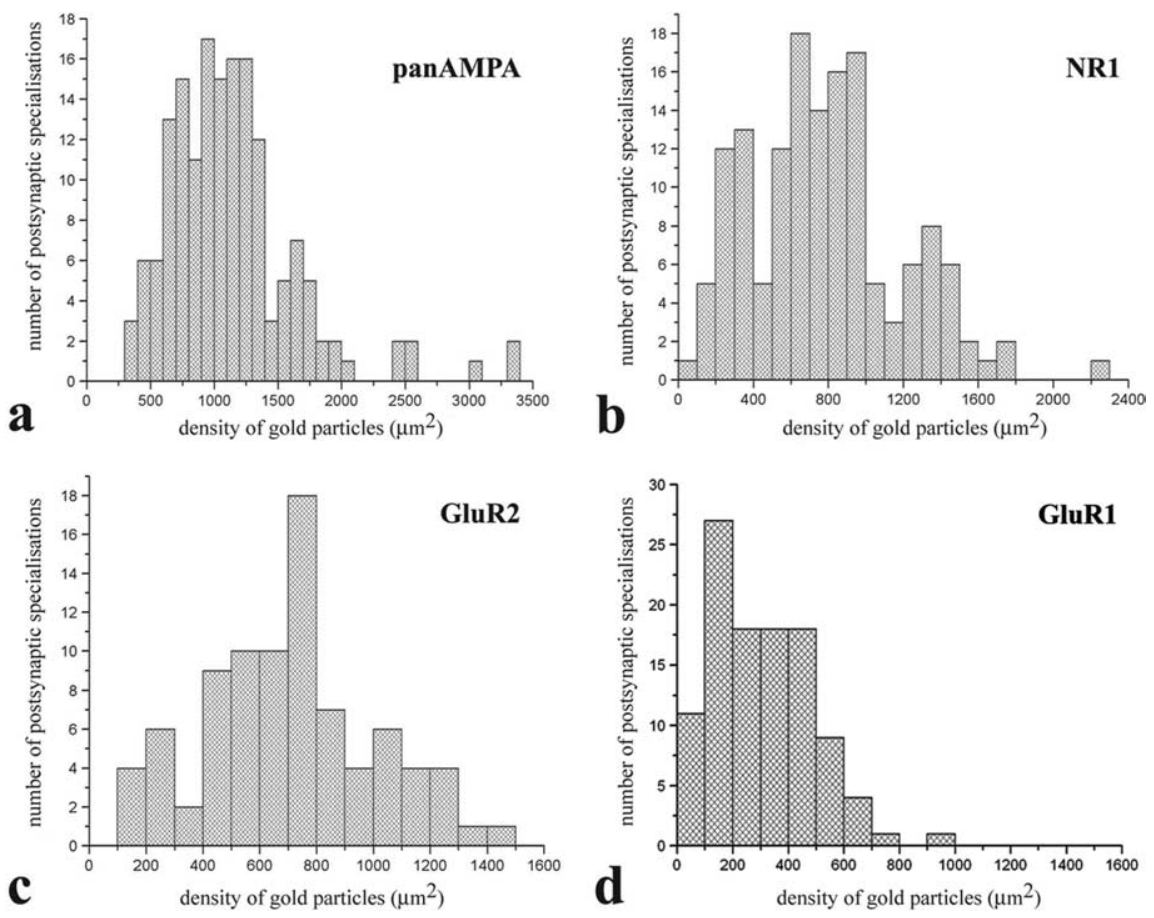

Figure 3. $\boldsymbol{a}-\boldsymbol{d}$, Histograms showing the distribution of densities of gold particles that label various subunits of AMPA- $(\boldsymbol{a}, \boldsymbol{c}, \boldsymbol{d})$ and NMDA- ( $\boldsymbol{b}$ ) type glutamate receptors in SDS-FRL replicas of individual postsynaptic membrane specializations in the superficial spinal dorsal horn of rats. Replicas from which data were obtained were immunolabeled with antibodies that recognize all subunits (pan-AMPA) (a) of AMPA receptors, NR1 subunits of NMDA receptors ( $\boldsymbol{b})$, and GluR2 (c) and GluR1 (d) subunits of AMPA receptors.

densities of immunogold labeling for the pan-AMPA antibody obtained from complete and incomplete postsynaptic active zones were not significantly different (supplemental Fig. 4, available at www.jneurosci.org as supplemental material), they were pooled. The density values varied in the range of 325-3365 particles $/ \mu \mathrm{m}^{2}$ with a median of 1115 particles $/ \mu \mathrm{m}^{2}$ (Fig. $3 a$ ). The mean density values for the extrasynaptic sites on E-face and background estimated on P-face were 2.7 and 3.2 particles $/ \mu \mathrm{m}^{2}$, respectively.

\section{Numbers and densities of NMDA receptors at individual synaptic contact areas}

To investigate the numbers, distribution, and densities of NMDA receptors at individual synaptic contact areas in the superficial spinal dorsal horn, replicas were reacted with a monoclonal antibody against the NR1 subunit, which is a constituent of all functional NMDA receptor ion channels [for review, see CullCandy et al. (2001) and Gibb (2004)]. The antibody was directed against a fusion protein corresponding to amino acid residues 660-811, representing the extracellular loop between transmembrane regions III and IV of the NR1 subunit (Siegel et al., 1994). It has been extensively documented that the antibody is highly specific and reacts selectively with NMDA receptors (Siegel et al., 1994)

Immunogold particles for NR1 were found almost exclusively on IMP clusters. The majority (96\%) of IMP clusters that contained at least 30 intramembrane particles and thus were regarded as postsynaptic membrane specialization on E-face profiles were immunoreactive for the NR1 antibody (Fig. 2b,d). Similarly to the AMPA receptor labeling, immunogold particles were randomly distributed over the entire field of IMP clusters without forming clusters, although the density of labeling varied from cluster to cluster (Fig. $3 b$; supplemental Fig. 3, available at www.jneurosci. org as supplemental material). In complete postsynaptic membrane specializations $(n=99)$, the number of gold particles varied in the range of 5-232 with a median value of 28 . The number of gold particles for NR1 showed a linear correlation ( $r=0.87)$ with the size of the postsynaptic surface areas (Fig. $4 b$ ). Because of the random distribution of gold particles (supplemental Fig. 3, available at www. jneurosci.org as supplemental material), data obtained from complete $(n=99)$ and incomplete $(n=48)$ postsynaptic membrane specialization were pooled for the calculation of densities of immunogold labeling for the NR1 antibody. The density values varied in the range of 102-2263 particles $/ \mu \mathrm{m}^{2}$ with a median of 777 particles/ $\mu \mathrm{m}^{2}$ (Fig. 3b). The shape of the density distribution histogram of NR1 labeling was very similar to that of pan-AMPA labeling.

\section{Colocalization of AMPA- and NMDA- type glutamate receptors at individual synaptic contact areas}

A synchronized train of repeated nociceptive input evokes a period of facilitated transmission in spinal dorsal horn neurons that resembles LTP in other parts of the CNS. This activitydependent form of central sensitization (spinal cord equivalent of LTP) is the consequence of activation of multiple intracellular signaling pathways that involves activation of both AMPA- and NMDA-type glutamate ionotropic receptors [for review, see Wolf and Salter (2000) and Ji et al. (2003)]. Because of its functional importance, we investigated the colocalization of AMPA and NMDA receptors at individual postsynaptic membrane specializations by simultaneous double labeling of replicas with panAMPA and NR1 antibodies.

The colocalization studies appeared to be very consistent. Although, because of spatial competition among the simultaneously applied antibodies, the signal intensity in double labeling for a given antibody was approximately one-half of that in single labeling, we found very similar distribution patterns of density in single and double labeling (data not shown). Regardless of whether AMPA receptors were labeled with $5 \mathrm{~nm}$ and NR1 subunits with $10 \mathrm{~nm}$ gold particles or vice versa, the majority of complete postsynaptic membrane specializations (179 of 186; 96.2\%) displayed positive labeling for both receptors (Fig. 5a,b, Table 1). Seven of the 186 postsynaptic membranes (3.8\%) investigated in this study were positive for pan-AMPA but negative for the NR1 (Fig. $5 c$, Table 1). However, postsynaptic membranes positive for NR1 and negative for pan-AMPA were not detected (Table 1).

\section{Numbers and densities of GluR2 subunits at individual synaptic contact areas}

A long line of experimental evidence suggests that the most prominently expressed AMPA receptor subunit in the spinal dorsal horn is GluR2 (Furuyama et al., 1993; Henley et al., 1993; Tölle et al., 1993, 1995). To investigate the distribution and densities of 
GluR2 subunits at individual synaptic contact areas in the superficial spinal dorsal horn of rats, replicas were reacted with a monoclonal antibody directed against a recombinant fusion protein corresponding to amino acid residues $175-430$, representing the $\mathrm{N}$-terminal portion of the receptor molecule. The antibody proved to be highly specific and appeared to react selectively with GluR2 subunits, because the application of the antibody to replicas of GluR2 knock-out mice did not result in any labeling (Fig. 6a), whereas strong immunolabeling was observed at IMP clusters on replicas of wild-type animals (Fig. $6 b)$.

Immunogold particles for GluR2 subunits were found almost exclusively on IMP clusters, and virtually all IMP clusters on E-face profiles were immunoreactive for the GluR2 antibody (Fig. 6c). The entire field of IMP clusters was densely but randomly labeled without clustering (supplemental Fig. 3, available at www. jneurosci.org as supplemental material), although the density of immunogold particles over individual IMP clusters was very variable (coefficient of variation $=0.437$ ) (Fig. $3 c$ ). In complete postsynaptic active zones $(n=62)$, the number of gold particles varied in the range of $4-162$ with a median value of 21 . The number of gold particles for GluR2 showed a linear correlation $(r=0.92)$ with the size of postsynaptic surface areas (Fig. $4 c$ ). Because of the random distribution of gold particles, data obtained from complete $(n=62)$ and incomplete $(n=24)$ postsynaptic membrane specializations were pooled for the calculation of densities of immunogold particles for the GluR2 antibody. The density values varied in the range of $144-1422$ particles/ $\mu \mathrm{m}^{2}$ with a median of 733 particles/ $\mu \mathrm{m}^{2}$. The shape of the density distribution histogram of GluR2 labeling showed a prominent peak at the median value (Fig. $3 c$ ).

\section{Numbers and densities of GluR1 subunits at individual synaptic contact areas}

With a little lag behind GluR2, the second most abundantly expressed AMPA receptor subunit in the superficial spinal dorsal horn is GluR1 (Furuyama et al., 1993; Tölle et al., 1993; Popratiloff et al., 1996; Engelman et al., 1999; Brown et al., 2002; Hartmann et al., 2004). Analogous to the predominant role of GluR1 in hippocampal LTP (Zamanillo et al., 1999) and spatial memory consolidation (Reisel et al., 2002), the presence of GluR1 subunit is required also for a rapid sensitization of glutamatergic synaptic events in the spinal dorsal horn (Hartmann et al., 2004). To investigate the distribution of GluR1 subunits, replicas were reacted with an antibody that was directed against residues 345-362, representing the putative $\mathrm{N}$-terminal extracellular portion of GluR1. The antibody appeared to be highly specific and reacted selectively with GluR1 subunits in Western blot analysis (supplemental Fig. 1, available at www.jneurosci.org as supplemental material). However, the application of the antibody to replicas of GluR1 knock-out mice showed substantial amount of labeling at IMP clusters (supplemental Fig. 2, available at www.jneurosci. org as supplemental material). Therefore we subtracted the re- b

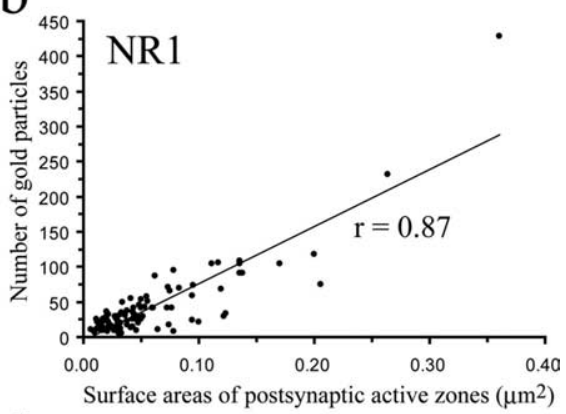

d

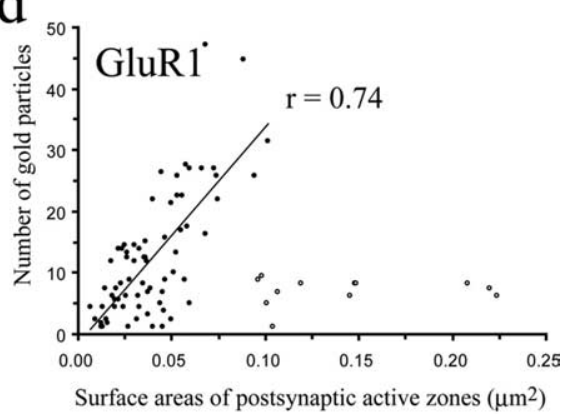

maining density of labeling in GluR1 knock-out animals from the labeling observed in rat samples. Thus, we reduced the numbers of gold particles and density of labeling to $63 \%$ of the original values (see Materials and Methods). These reduced values can be found in the next paragraph.

Immunogold particles for GluR1 subunits were found almost exclusively on IMP clusters, and $87 \%$ of IMP clusters on E-face profiles were considered immunoreactive for GluR1 (Fig. 6f). The entire field of IMP clusters was randomly labeled, and no clustering of immunoparticles was detected (supplemental Fig. 3, available at www.jneurosci.org as supplemental material), although the density of immunogold particles over individual IMP clusters was very variable (coefficient of variation $=0.67$ ). In complete postsynaptic active zones $(n=66)$, the number of gold particles varied in the range of $2-47$ with a median value of 9 . The number of gold particles for GluR1 showed a less linear correlation $(r=0.14)$ than that for GluR2 with the size of the postsynaptic surface areas. Searching for an explanation for this poor linear correlation, we found that there might be two populations of synapses, one with high and another with very low GluR1 densities. When we selected synapses larger than $0.06 \mu \mathrm{m}^{2}$, they could be clearly separated into two groups, one with a high mean density of GluR1 (240-696 particles/ $\mu \mathrm{m}^{2}$ with a median of 349 particles $/ \mu \mathrm{m}^{2}$ ) and another with $<10$ particles/synapse $(12-96$ particles $/ \mu \mathrm{m}^{2}$ with a median of 52 particles $/ \mu \mathrm{m}^{2}$ ) (labeled with open circles in Fig. $4 d$ ). Synapses larger than $0.1 \mu \mathrm{m}^{2}$ were all within the second group with very low particle density. Separating all synapses that showed low particle density and were larger than $0.06 \mu \mathrm{m}^{2}$ (labeled with open circles in Fig. $4 d$ ) from the total population, the number of gold particles for GluR1 in the rest of the synapses showed a nice linear correlation $(r=0.74)$ with the size of postsynaptic surface areas (Fig. $4 d$ ). 

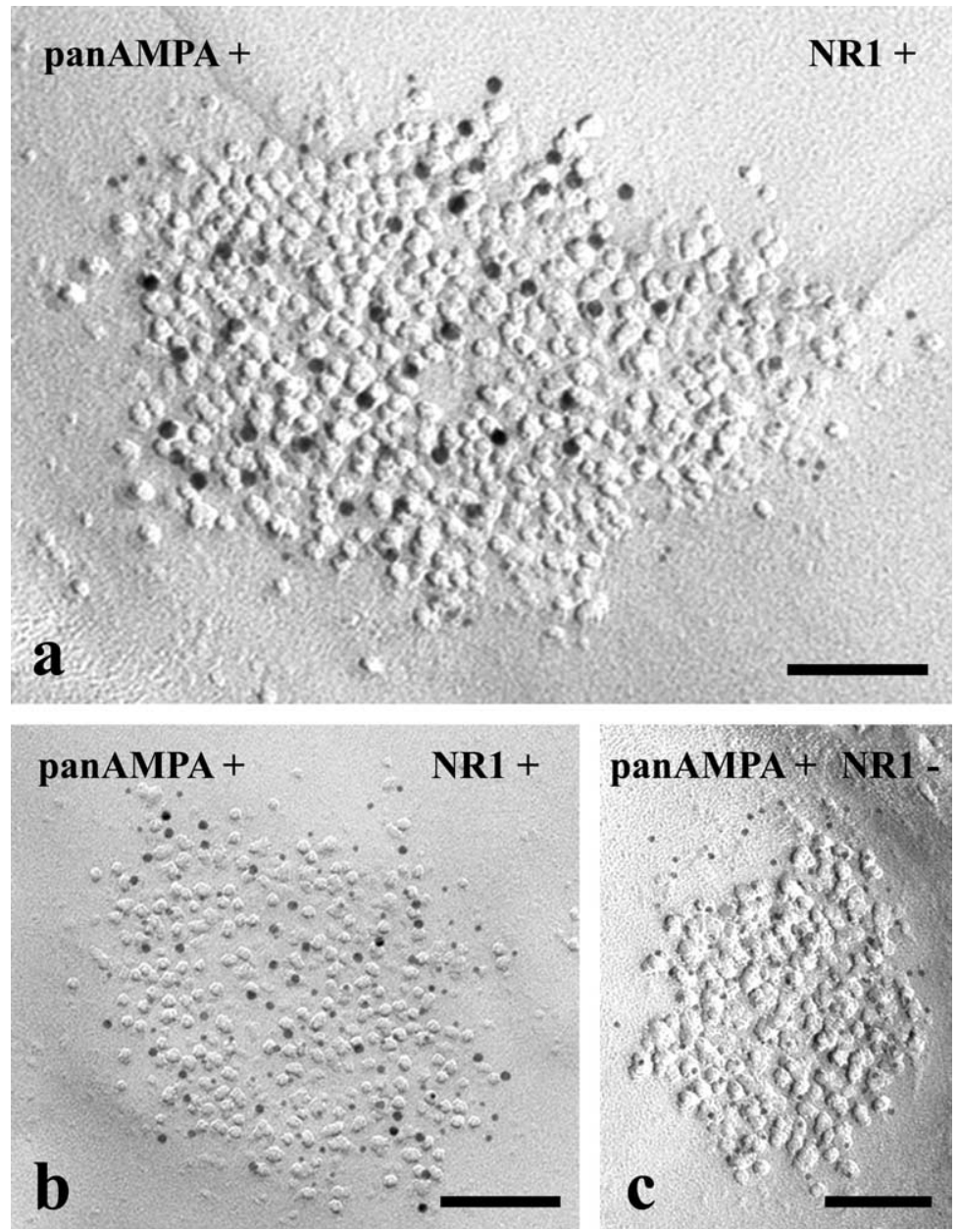

Figure 5. Electron micrographs of SDS-FRL replicas simultaneously double immunolabeled with antibodies raised against the NR1 subunit of NMDA-type glutamate receptors and an amino acid sequence that is common in all subunits of AMPA-type glutamate receptors (pan-AMPA). $\boldsymbol{a}-\boldsymbol{c}$, AMPA receptors are labeled with $10 \mathrm{~nm}$ gold particles, and NR1 subunits are marked with $5 \mathrm{~nm}$ gold particles in $\boldsymbol{a}$, whereas $5 \mathrm{~nm}$ gold particles label AMPA receptors, and $10 \mathrm{~nm}$ gold particles mark NR1 subunits in $\boldsymbol{b}$ and c. Postsynaptic membrane specializations in the micrographs in $\boldsymbol{a}$ and $\boldsymbol{b}$ show immunoreactivity for both antibodies, whereas postsynaptic membrane specializations in the micrograph in c are positive for pan-AMPA but negative for NR1. Scale bars, $0.1 \mu \mathrm{m}$.

\section{Sizes of postsynaptic membrane specializations}

Finally, we pooled all complete postsynaptic membrane specializations that showed any kind of positive labeling for AMPA and/or NMDA receptor subunits. Thus we collected 740 postsynaptic membrane specializations of glutamatergic synaptic contacts in laminae I-II of the spinal dorsal horn of rats, and measured their surface areas by Scion Image. Although the types of neurons that presented the postsynaptic membrane specializations as well as the origin of presynaptic axon terminals that were associated with the investigated postsynaptic membranes could be very heterogeneous in our sample, the distribution histogram of surface areas of postsynaptic membrane specializations showed only one peak (Fig. 7). The surface areas of individual postsynaptic membrane specializations varied in the range of $0.0026-0.3609 \mu \mathrm{m}^{2}$ (median, $0.0419 \mu \mathrm{m}^{2}$ ); only $26(3.5 \%)$ of the 740 postsynaptic membrane specializations were larger than $0.15 \mu \mathrm{m}^{2}$.

\section{Discussion}

Applying the SDS-FRL method, which has almost one gold particle-one functional channel sensitivity (Tanaka et al., 2005) to laminae I-II of the spinal dorsal horn of rats, we showed that virtually all glutamatergic postsynaptic membranes in laminae I-II expressed AMPA and NMDA receptors. Furthermore, most of them were immunoreactive for GluR2, whereas GluR1 is expressed in selective populations of the synapses. In synapses larger than $0.1 \mu \mathrm{m}^{2}$, GluR1 subunits were recovered in very low numbers. This differential expression of GluR1 and GluR2 subunits was encountered even at synapses that were located in a close vicinity to each other on the very same neuron (supplemental Fig. 5, available at www. jneurosci.org as supplemental material). Nevertheless, the numbers of gold particles for AMPA and NMDA receptors showed linear correlations with the size of postsynaptic surface areas.

It is very likely that in our present study we investigated the postsynaptic membrane specializations of a quite heterogeneous population of synaptic contacts. Cand $\mathrm{A} \delta$-type primary afferents as well as excitatory local interneurons all form glutamatergic synaptic contacts with various types of neurons in laminae I-II of the spinal dorsal horn. Despite this heterogeneity, however, the densities of AMPA and NMDA receptor subunits as well as surface areas of the postsynaptic membrane specializations showed homogeneous distributions. Synapses could be clearly divided into two groups only on the basis of their GluR1 subunit densities.

\section{Size of individual postsynaptic membrane specializations}

Synaptic structure plays a key role in synaptic transmission (Walmsley et al., 1998). In addition to presynaptic mechanisms, postsynaptic responses may be influenced by the number and density of postsynaptic receptors, which in turn may be related to the size of the postsynaptic membrane specializations (Nusser et al., 1997; Lim et al., 1999; Mackenzie et al., 1999; Nusser, 2000). Because of their functional importance, morphological parameters of postsynaptic active zones have extensively been studied in various brain regions, and a considerable variability has been observed (Antal et al., 1992; Pierce and Mendel, 1993; Ryugo et al., 1996; Taschenberg et al., 2002). For instance, the sizes of postsynaptic membrane specializations at cerebellar climbing fiber and parallel fiber synapses are among the largest on average $\left(0.14 \mu \mathrm{m}^{2}\right)(\mathrm{Xu}-$ Friedman et al., 2001), whereas this value has been defined at around only $0.04-0.07 \mu \mathrm{m}^{2}$ on CA1 dendritic spines (Schikorski and Stevens, 1997; Shepherd and Harris, 1998). The size distribution of individual postsynaptic membrane specializations that we encountered in laminae I-II of the spinal dorsal horn of rats appears to be similar to the ones that have been observed on CA1 dendritic spines.

\section{Numbers and densities of AMPA and NMDA receptors}

The number of ionotropic receptors in synapses is an essential factor for determining the efficacy of fast neural transmission. As 
Table 1. Numbers and percentage of complete postsynaptic membrane specializations immunoreactive for pan-AMPA and/or NR1 subunit of NMDA receptor in the superficial spinal dorsal horn

\begin{tabular}{llllc}
\hline & pan-AMPA+, NR1+ & pan-AMPA+, NR1- & pan-AMPA-, NR1+ & Total \\
\hline pan-AMPA-10 nm, NR1-5 nm & 89 & 3 & 0 & 92 \\
pan-AMPA-5 nm, NR1-10 nm & 90 & 4 & 0 & 94 \\
Total & 179 & 7 & 0 & 186 \\
& $(96.2 \%)$ & $(3.8 \%)$ & & $(100 \%)$ \\
\hline
\end{tabular}
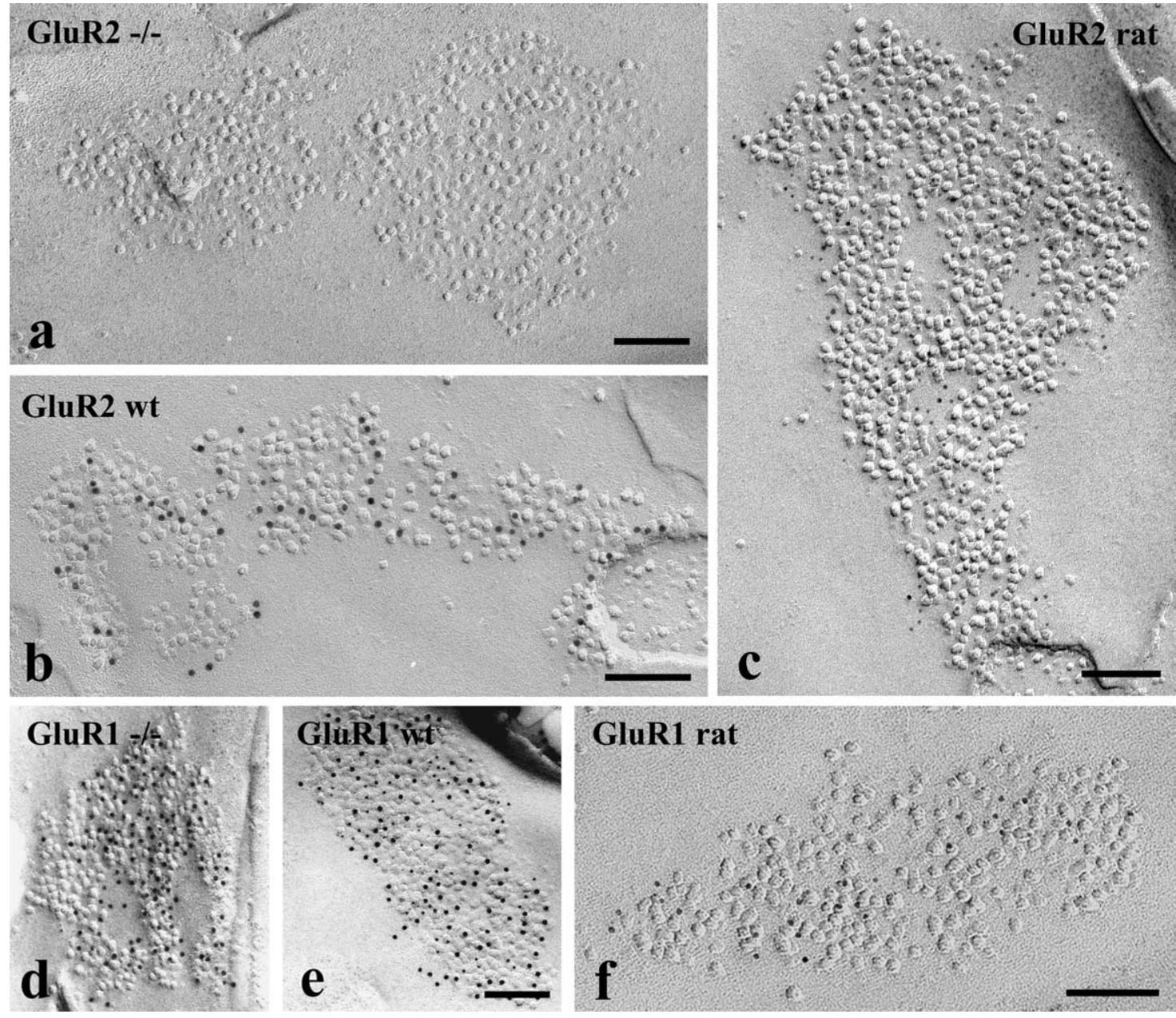

Figure 6. Electron micrographs of SDS-FRL replicas immunolabeled with antibodies that recognize GluR2 or GluR1 subunits. $\boldsymbol{a}-\boldsymbol{f}$, The micrographs illustrate postsynaptic membrane specializations (IMP clusters) in the superficial spinal dorsal horn of GluR2 ( $(\boldsymbol{a})$ and GluR1 (d) knock-out mice and wild-type (wt) mice $(\boldsymbol{b}, \boldsymbol{e})$ and rats $(\boldsymbol{c}, \boldsymbol{f})$. SDS-FRL replicas from GluR2 knock-out mice $(\boldsymbol{a})$ and wild-type mice $(\boldsymbol{b})$ and rats (c) were labeled for GluR2. The postsynaptic membrane specializations are free of labeling in the GluR2 knock-out animal (a), and show strong immunoreactivity for GluR2 in the wild-type mice $(\boldsymbol{b})$ and rats $(\boldsymbol{c})$. SDS-FRL replicas from GluR1 knock-out $(\boldsymbol{d})$ and wild-type $(\boldsymbol{e})$ mice were double labeled for GluR1 and GluR2, whereas replicas from a rat were labeled only for GluR1 $(\boldsymbol{f})$. The postsynaptic membrane specializations from GluR1 knock-out animals are positively labeled for GluR2 but negative for GluR1 (d). The postsynaptic membrane specialization from wild-type mice are positive for both GluR1 and GluR2 (e), whereas postsynaptic membrane specialization from a rat show strong immunoreactivity for GluR1 $(\boldsymbol{f})$. GluR2 subunits were labeled with $10 \mathrm{~nm}(\boldsymbol{b}, \boldsymbol{d}, \boldsymbol{e})$ and $5 \mathrm{~nm}(\boldsymbol{c})$, whereas GluR1 subunits were labeled with $5 \mathrm{~nm}(\boldsymbol{d}, \boldsymbol{e})$ and $10 \mathrm{~nm}(\boldsymbol{f})$ gold particles. Scale bars, $0.1 \mu \mathrm{m}$.

a general rule for both glutamatergic and GABAergic ionotropic receptors, it appears that the number of functional receptors is proportional to the synaptic area in a particular type of synapse. The receptor density, however, shows a great deal of variability, which may derive from difference in types of synapses investigated or quantitative methods used in the different studies (Nusser et al., 1998; Somogyi et al., 1998a; Nusser, 1999; Tanaka et al., 2005; MasugiTokita et al., 2007). The average immunogold particle density that we observed in laminae I-II of the spinal dorsal horn for AMPA receptors was close to the figure that was obtained at synaptic contacts between mossy fibers and cerebellar granule cells $(\sim 1000$ receptors $/ \mu \mathrm{m}^{2}$ ) (Silver et al., 1996). However, it is important to note that we investigated a heterogeneous population of synaptic contacts established by nociceptive primary afferents, segmental and intersegmental propriospinal axons with various spinal neurons that may possess AMPA and NMDA receptors in different quantities. Actually, our results suggest that the densities of AMPA and NMDA receptors at individual postsynaptic membrane specializations of various groups of synaptic appositions in the superficial spinal dorsal horn of rats can really be heterogeneous. According to the nonGaussian distribution of immunogold particle densities (Fig. 4a), the density values may vary from $400-500$ to $1800-2000$ receptors $/ \mu \mathrm{m}^{2}$ for AMPA receptors. Similar variation was also found for NMDA receptor density. 


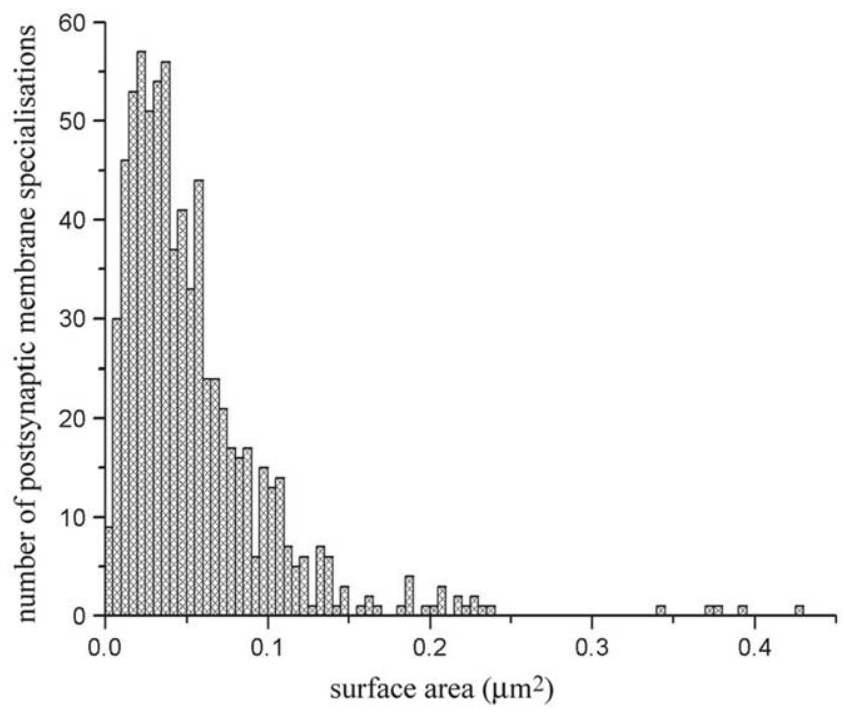

Figure 7. Histogram showing the distribution of surface areas of complete postsynaptic membrane specializations expressing AMPA- and/or NMDA-type glutamate receptors in the superficial spinal dorsal horn of rats.

It is also important to note that extrasynaptic membrane compartments showed remarkably weak, if any, immunolabeling for both AMPA and NMDA receptor subunits, indicating that extrasynaptic ionotropic receptors may play a negligible role in glutamatergic coupling among neurons in the superficial spinal dorsal horn.

\section{Colocalization of AMPA and NMDA receptors}

We found that all synaptic contacts that expressed NMDA receptors also contained AMPA receptors in laminae I-II of the rat spinal gray matter. In addition, none of the postsynaptic membranes recovered in this study carried less than eight gold particles marking AMPA receptors. These findings confirm earlier physiological studies, concluding that there is no direct evidence for the presence of "silent" synapses (NMDA receptorcontaining synapses without functional AMPA receptors) in the spinal dorsal horn of adult animals, although their presence has been confirmed in the neonatal rat (Bardoni et al., 1998; Li and Zhuo, 1998; Baba et al., 2000). Thus, it appears that pure-NMDA receptor-mediated EPSCs are transient, developmentally regulated phenomena, and although they may have a role in synaptic refinement in the immature dorsal horn, they are unlikely to be involved in nociceptive information processing mechanisms in the adult.

It has been suggested that AMPA and NMDA receptors might be arranged in functional microdomains within synaptic membranes. The notion is based on results obtained in independent laboratories, suggesting that the distribution of AMPA receptors may not be uniform over the postsynaptic density but more concentrated laterally, whereas NMDA receptors are located centrally (Matsubara et al., 1996; Kharazia and Weinberg, 1997; Somogyi et al., 1998b; He et al., 2001). Other theories, however, claim just the opposite and argue in favor of a uniform distribution of ionotropic glutamate receptors over synaptic membrane specializations (Nusser et al., 1994, 1998, Masugi-Tokita et al., 2007). Although we cannot exclude the possibility that subsynaptic organization of receptors might have changed during specimen preparation, our present results support the "homogeneous distribution" theory for spinal cord synapses. The high sensitivity and two-dimensional resolution of SDS-FRL have revealed a rather homogeneous distribution of both AMPA and NMDA receptors within individual postsynaptic membrane specializations. This type of receptor distribution may have profound biological significance; it may make the cooperation between AMPA and NMDA receptor mechanisms direct and very effective.

\section{Subunit composition of AMPA receptors}

AMPA receptors with different subunit composition have characteristic pharmacological and physiological properties (for review, see Harris, 1995). For instance, the presence of GluR2 subunits renders heteromeric AMPA receptor assemblies $\mathrm{Ca}^{2+}$ impermeable, whereas receptors lacking GluR2 subunits are $\mathrm{Ca}^{2+}$ permeable (Gasic and Heinemann, 1991; Hollmann et al., 1991; Verdoorn et al., 1991; Burnashev et al., 1992; Sommer and Seeburg, 1992; Pellegrini-Giampietro et al., 1997; Swanson et al., 1997). A great deal of earlier experimental evidence indicated that different populations of neurons in the superficial spinal dorsal horn show differential AMPA receptor expression. Kainateinduced cobalt-uptake and immunocytochemical studies strongly indicated that a majority of neurons immunoreactive for GABA are positively stained for GluR1 but not GluR2 and do express $\mathrm{Ca}^{2+}$-permeable AMPA receptors, whereas several subpopulations of putative excitatory interneurons do not express $\mathrm{Ca}^{2+}$-permeable AMPA receptors (Kerr et al., 1998; Albuquerque et al., 1999; Engelman et al., 1999). The contrasting distribution of GluR1 and GluR2/3 immunoreactivity raised the possibility that some neurons in the superficial dorsal horn may express only one of the two receptor subunits. Other studies, however, suggested that individual dorsal horn neurons can express both $\mathrm{Ca}^{2+}$-permeable and $\mathrm{Ca}^{2+}$-impermeable AMPA receptors (Goldstein et al., 1995; Gu et al., 1996; Albuquerque et al., 1999). This notion was strongly reinforced by a recent immunofluorescence study showing that virtually all GluR1-immunoreactive puncta that were assumed to represent postsynaptic membranes were also GluR2 immunoreactive throughout the dorsal horn (Nagy et al., 2004).

Although immunocytochemical colocalization studies provide only circumstantial evidence regarding the subunit composition of individual AMPA receptor complexes, our present findings are in agreement with the report of Nagy et al. (2004). We also found that the majority of complete postsynaptic membrane specializations (99\%) displayed positive immunolabeling for GluR2, and most of them (87\%) were also immunoreactive for GluR1. On the other hand, however, although the overlap between GluR1 and GluR2 immunoreactivity was high, the numbers of gold particles labeling GluR1 and GluR2 molecules varied at individual postsynaptic active zones. It is therefore likely that the targeting of AMPA receptor subunits to individual postsynaptic membranes is remarkably complex. Different AMPA receptor ion channels within the same postsynaptic membrane may present different subunit composition. $\mathrm{Ca}^{2+}$-permeable AMPA receptors can be intermingled with GluR2-containing receptors within the same postsynaptic active zones, and the ratio between $\mathrm{Ca}^{2+}$-permeable and $\mathrm{Ca}^{2+}$-impermeable AMPA receptors may vary in a wide range. Moreover, we encountered this differential expression of GluR1 and GluR2 subunits even at postsynaptic membrane specializations that were located in a close vicinity to each other on the same neuron, indicating that the targeting of AMPA receptor subunits to postsynaptic membranes might be regulated by presynaptic mechanisms. 


\section{References}

Albuquerque C, Lee CJ, Jackson AC, MacDermott AB (1999) Subpopulations of GABAergic and non-GABAergic rat dorsal horn neurons express $\mathrm{Ca}^{2+}$-permeable AMPA receptors. Eur J Neurosci 11:2758-2766.

Antal M, Kraftsik R, Székely G, van der Loos H (1992) Synapses on motoneuron dendrites in the brachial section of the frog spinal cord: a computer-aided electron microscopic study of cobalt-filled cells. J Neurocytol 21:34-49.

Baba H, Doubell TP, Moore KA, Woolf CJ (2000) Silent NMDA receptormediated synapses are developmentally regulated in the dorsal horn of the rat spinal cord. J Neurophysiol 83:955-962.

Bardoni R, Magherini PC, MacDermott AB (1998) NMDA EPSCs at glutamatergic synapses in the spinal cord dorsal horn of the postnatal rat. J Neurosci 18:6558-6567.

Baude A, Nusser Z, Molnár E, McIlhinney RA, Somogyi P (1995) Highresolution immunogold localization of AMPA type glutamate receptor subunits at synaptic and non-synaptic sites in rat hippocampus. Neuroscience 69:1031-1055.

Brown KM, Wrathall JR, Yasuda RP, Wolfe BB (2002) Quantitative measurement of glutamate receptor subunit protein expression in the postnatal rat spinal cord. Brain Res Dev Brain Res 137:127-133.

Burnashev N, Monyer H, Seeburg PH, Sakmann B (1992) Divalent ion permeability of AMPA receptor channels is dominated by the edited form of a single subunit. Neuron 8:189-198.

Cull-Candy S, Brickley S, Farrant M (2001) NMDA receptors subunits: diversity, development and disease. Curr Opin Neurobiol 11:327-335.

Engelman HS, Allen TB, MacDermott AB (1999) The distribution of neurons expressing calcium-permeable AMPA receptors in the superficial laminae of the spinal cord dorsal horn. J Neurosci 19:2081-2089.

Fritschy JM, Weinmann O, Wenzel A, Benke D (1998) Synapse-specific localization of NMDA and GABA(A) receptor subunits revealed by antigen-retrieval immunohistochemistry. J Comp Neurol 390:194-210.

Fujita A, Cheng J, Hirakawa M, Furukawa K, Kusunoki S, Fujimoto T (2007) Gangliosides GM1 and GM3 in the living cell membrane form clusters susceptible to cholesterol depletion and chilling. Mol Biol Cell 18:2112-2122.

Furuyama T, Kiyama H, Sato K, Park HT, Maeno H, Takagi H, Tohyama M (1993) Region-specific expression of subunits of ionotropic glutamate receptors (AMPA-type, KA-type and NMDA receptors) in the rat spinal cord with special reference to nociception. Mol Brain Res 18:141-151.

Gasic GP, Heinemann S (1991) Receptors coupled to ionic channels: the glutamate receptor family. Curr Opin Neurobiol 1:20-26.

Gibb AJ (2004) NMDA receptor subunit gating-uncovered. Trends Neurosci $27: 7-10$

Goldstein PA, Lee CJ, MacDermott AB (1995) Variable distributions of $\mathrm{Ca}^{2+}$-permeable and $\mathrm{Ca}^{2+}$-impermeable AMPA receptors on embryonic rat dorsal horn neurons. J Neurophysiol 73:2522-2534.

Gu JG, Albuquerque C, Lee CJ, MacDermott AB (1996) Synaptic strengthening through activation of $\mathrm{Ca}^{2+}$-permeable AMPA receptors. Nature 381:793-796.

Harris EW (1995) Subtypes of glutamate receptors: pharmacological classification. In: CNS neurotransmitters and neuromodulators (Stone TW, ed), pp 95-125. Boca Raton, FL: CRC.

Harris JA, Corsi M, Quartaroli M, Arban R, Bentivoglio M (1996) Upregulation of spinal glutamate receptors in chronic pain. Neuroscience 74:7-12.

Harris KM, Landis DM (1986) Membrane structure at synaptic junctions in area CA1 of the rat hippocampus. Neuroscience 19:857-872.

Hartmann B, Ahmadi S, Heppenstall PA, Lewin GR, Schott C, Borchardt T, Seeburg PH, Zeilhofer HU, Sprengel R, Kuner R (2004) The AMPA receptor subunits GluR-A and GluR-B reciprocally modulate spinal synaptic plasticity and inflammatory pain. Neuron 44:637-650.

He Y, Hof PR, Janssen WG, Rothstein JD, Morrison JH (2001) Differential synaptic localization of GluR2 and EAAC1 in the macaque monkey entorhinal cortex: a postembedding immunogold study. Neurosci Lett 311:161-164.

Henley JM, Jenkins R, Hunt SP (1993) Localization of glutamate receptor binding sites and mRNAs to the dorsal horn of the rat spinal cord. Neuropharmacology 32:37-41.

Hollmann M, Hartley M, Heinemann S (1991) Ca2+ permeability of KAAMPA-gated glutamate receptor channels depends on subunit composition. Science 252:851-853.
Jakowec MW, Fox AJ, Martin LJ, Kalb RG (1995a) Quantitative and qualitative changes in AMPA receptor expression during spinal cord development. Neuroscience 67:893-907.

Jakowec MW, Yen L, Kalb RG (1995b) In situ hybridization analysis of AMPA receptor subunit gene expression in the developing rat spinal cord. Neuroscience 67:909-920.

Ji RR, Kohno T, Moore KA, Woolf CJ (2003) Central sensitization and LTP: do pain and memory share similar mechanisms? Trends Neurosci 26:696-705.

Kerr R, Maxwell DJ, Todd AJ (1998) GluR1 and GluR2/3 subunits of the AMPA-type glutamate receptor are associated with particular types of neurone in laminae I-III of the spinal dorsal horn of the rat. Eur J Neurosci 10:324-333.

Kharazia VN, Weinberg RJ (1997) Tangential synaptic distribution of NMDA and AMPA receptors in rat neocortex. Neurosci Lett 238:41-44.

Landis DM, Reese TS (1974) Differences in membrane structure between excitatory and inhibitory synapses in the cerebellar cortex. J Comp Neurol 155:93-125.

Li P, Zhuo M (1998) Silent glutamatergic synapses and nociception in mammalian spinal cord. Nature 393:695-698.

Lim R, Alvarez FJ, Walmsley B (1999) Quantal size is correlated with receptor cluster area at glycinergic synapses in the rat brainstem. J Physiol 516:505-512.

Mackenzie PJ, Kenner GS, Prange O, Shayan H, Umemiya M, Murphy TH (1999) Ultrastructural correlates of quantal synaptic functions at single CNS synapses. J Neurosci 19:RC13(1-7).

Masugi-Tokita M, Shigemoto R (2007) High-resolution quantitative visualization of glutamate and GABA receptors at central synapses. Curr Opin Neurobiol 17:387-393.

Masugi-Tokita M, Tarusawa E, Watanabe M, Molnár E, Fujimoto K, Shigemoto R (2007) Number and density of AMPA receptors in individual synapses in the rat cerebellum as revealed by SDS-digested freeze-fracture replica labeling. J Neurosci 27:2135-2144.

Matsubara A, Laake JH, Davanger S, Usami S, Ottersen OP (1996) Organization of AMPA receptor subunits at a glutamate synapse: a quantitative immunogold analysis of hair cell synapses in the rat organ of Corti. J Neurosci 16:4457-4467.

McClung JR, Castro AJ (1978) Rexed's laminar scheme as it applies to the rat cervical spinal cord. Exp Neurol 58:145-148.

McNeill DL, Chung K, Hulsebosch CE, Bolender RP, Coggeshall RE (1988) Numbers of synapses in laminae I-IV of the rat dorsal horn. J Comp Neurol 278:453-460.

Molander C, Xu Q, Grant G (1984) The cytoarchitectonic organization of the spinal cord in the rat. I. The lower thoracic and lumbosacral cord. J Comp Neurol 230:133-141.

Nagy GG, Al-Ayyan M, Andrew D, Fukaya M, Watanabe M, Todd AJ (2004) Widespread expression of the AMPA receptor GluR2 subunit at glutamatergic synapses in the rat spinal cord and phosphorylation of GluR1 in response to noxious stimulation revealed with an antigen-unmasking method. J Neurosci 24:5766-5777.

Nakanishi S (1992) Molecular diversity of glutamate receptors and implications for brain function. Science 258:597-603.

Nusser Z (1999) A new approach to estimate the number, density and variability of receptors at central synapses. Eur J Neurosci 11:745-752.

Nusser Z (2000) AMPA and NMDA receptors: similarities and differences in their synaptic distribution. Curr Opin Neurobiol 10:337-341.

Nusser Z, Mulvihill E, Streit P, Somogyi P (1994) Subsynaptic segregation of metabotropic and ionotropic glutamate receptors as revealed by immunogold localization. Neuroscience 61:421-427.

Nusser Z, Cull-Candy S, Farrant M (1997) Differences in synaptic GABA receptor number underlie variation in GABA mini amplitude. Neuron 19:697-709.

Nusser Z, Lujan R, Laube G, Roberts JDB, Molnar E, Somogyi P (1998) Cell type and pathway dependence of synaptic AMPA receptor number and variability in the hippocampus. Neuron 21:545-559.

Ottersen OP, Landsend AS (1997) Organization of glutamate receptors at the synapse. Eur J Neurosci 9:2219-2224.

Pellegrini-Giampietro DE, Fan S, Ault B, Miller BE, Zukin RS (1994) Glutamate receptor gene expression in spinal cord of arthritic rats. J Neurosci 14:1576-1583.

Pellegrini-Giampietro DE, Gorter JA, Bennett MV, Zukin RS (1997) The 
GluR2 (GluR-B) hypothesis: $\mathrm{Ca}(2+)$-permeable AMPA receptors in neurological disorders. Trends Neurosci 20:464-470.

Pierce JP, Mendell LM (1993) Quantitative ultrastructure of Ia boutons in the ventral horn: scaling and positional relationships. J Neurosci 13:4748-4763.

Popratiloff A, Weinberg RJ, Rustioni A (1996) AMPA receptor subunits underlying terminals of fine-caliber primary afferent fibers. J Neurosci 16:3363-3372.

Popratiloff A, Weinberg RJ, Rustioni A (1998) AMPA receptors at primary afferent synapses in substantia gelatinosa after sciatic nerve section. Eur J Neurosci 10:3220-3230.

Popratiloff SA, Weinberg JR, Rustioni A (1998) NMDAR1 and primary afferent terminals in the superficial spinal cord. Neuroreport 9:2423-2429.

Prior IA, Muncke C, Parton RG, Hancock JF (2003) Direct visualization of Ras proteins in spatially distinct cell surface microdomains. J Cell Biol 160:165-170.

Ragnarson B, Ornung G, Grant G, Ottersen OP, Ulfhake B (2003) Glutamate and AMPA receptor immunoreactivity in Ia synapses with motoneurons and neurons of the central cervical nucleus. Exp Brain Res 149:447-457.

Ripley BD (1977) Modelling spatial patterns. J R Stat Soc Ser B Stat Methodol 39:172-192.

Ripley BD (1979) Tests of randomness for spatial point patterns. J R Stat Soc Ser B Stat Methodol 41:368-374.

Ryugo DK, Wu MM, Pongstaporn T (1996) Activity-related features of synapse morphology: a study of endbulbs of Held. J Comp Neurol 365:141-158.

Sato K, Kiyama H, Tohyama M (1993) The differential expression patterns of messenger RNAs encoding non- $N$-methyl-D-aspartate glutamate receptor subunits (GluR1-4) in the rat brain. Neuroscience 52:515-539.

Schikorski T, Stevens CF (1997) Quantitative ultrastructural analysis of hippocampal excitatory synapses. J Neurosci 17:5858-5867.

Shepherd GMG, Harris KM (1998) Three-dimensional structure and composition of CA3-CA1 axons in the rat hippocampal slices: implications for presynaptic connectivity and compartmentalization. J Neurosci 18:8300-8310.

Siegel SJ, Brose N, Janssen WG, Gasic GP, Jahn R, Heinemann SF, Morrison JH (1994) Regional, cellular, and ultrastructural distribution of $\mathrm{N}$-methyl-D-aspartate receptor subunit 1 in monkey hippocampus. Proc Natl Acad Sci U S A 91:564-568.

Silver RA, Cull-Candy SG, Takahashi T (1996) Non-NMDA glutamate receptor occupancy and open probability at a rat cerebellar synapse with single and multiple release sites. J Physiol 494:231-250.

Sommer B, Seeburg PH (1992) Glutamate receptor channels: novel properties and new clones. Trends Pharmacol Sci 13:291-296.

Somogyi P, Nusser Z, Roberts JDB, Lujan R (1998a) Precision and variability in the placement of pre- and postsynaptic receptors in relation to neurotransmitter release sites. In: Central synapses: quantal mechanisms and plasticity, Vol 4 (Faber DS, Korn H, Thompson SM, Redman SF, Altman FS, eds), pp 82-93. Strasbourg, France: HFSP.

Somogyi P, Tamás G, Lujan R, Buhl EH (1998b) Salient features of synaptic organization in the cerebral cortex. Brain Res Brain Res Rev 26:113-135.

Sorkin LS, Yaksh TL, Doom CM (1999) Mechanical allodynia in rats is blocked by a $\mathrm{Ca}^{2+}$ permeable AMPA receptor antagonist. Neuroreport 10:3523-3526.

Swanson GT, Kamboj SK, Cull-Candy SG (1997) Single channel properties of recombinant AMPA receptors depend on RNA editing, splice variation, and subunit composition. J Neurosci 17:58-69.

Tachibana M, Wenthold RJ, Morioka H, Petralia RS (1994) Light and electron microscopic immunocytochemical localization of AMPA-selective glutamate receptors in the rat spinal cord. J Comp Neurol 344:431-454.

Takumi Y, Ramírez-León V, Laake P, Rinvik E, Ottersen OP (1999) Different modes of expression of AMPA and NMDA receptors in hippocampal synapses. Nat Neurosci 2:618-624.

Tanaka J, Matsuzaki M, Tarusawa E, Momiyama A, Molnar E, Kasai H, Shigemoto R (2005) Number and density of AMPA receptors in single synapses in immature cerebellum. J Neurosci 25:799-807.

Taschenberger H, Leão RM, Rowland KC, Spirou GA, von Gersdorff $\mathrm{H}$ (2002) Optimizing synaptic architecture and efficiency for highfrequency transmission. Neuron 36:1127-1143.

Tölle TR, Berthele A, Zieglgänsberger W, Seeburg PH, Wisden W (1993) The differential expression of 16 NMDA and non-NMDA receptor subunits in the rat spinal cord and in periaqueductal gray. J Neurosci 13:5009-5028.

Tölle TR, Berthele A, Zieglgänsberger W, Seeburg PH, Wisden W (1995) Flip and flop variants of AMPA receptors in the rat lumbar spinal cord. Eur J Neurosci 7:1414-1419.

Verdoorn TA, Burnashev N, Monyer H, Seeburg PH, Sakmann B (1991) Structural determinants of ion flow through recombinant glutamate receptor channels. Science 252:1715-1718.

Walmsley B, Alvarez FJ, Fyffe REW (1998) Diversity of structure and function at mammalian central synapses. Trends Neurosci 21:81-88.

Watanabe M, Fukaya M, Sakimura K, Manabe T, Mishina M, Inoue Y (1998) Selective scarcity of NMDA receptor channel subunits in the stratum lucidum (mossy fiber-recipient layer) of the mouse hippocampal CA3 subfield. Eur J Neurosci 10:478-487.

Woolf CJ, Salter MW (2000) Neuronal plasticity: increasing the gain in pain. Science 288:1765-1769.

Xu-Friedman MA, Harris KM, Regehr WG (2001) Three-dimensional comparison of ultrastructural characteristics at depressing and facilitating synapses onto cerebellar Purkinje cells. J Neurosci 21:6666-6672.

Zamanillo D, Sprengel R, Hvalby O, Jensen V, Burnashev N, Rozov A, Kaiser KM, Köster HJ, Borchardt T, Worley P, Lübke J, Frotscher M, Kelly PH, Sommer B, Andersen P, Seeburg PH, Sakmann B (1999) Importance of AMPA receptors for hippocampal synaptic plasticity but not for spatial learning. Science 284:1805-1811. 